Bond University ePublications@bond

Sports Law eJournal

Faculty of Law

2-19-2015

\title{
Constitutional Dimensions of Sport in Greece
}

Konstantinos Margaritis

Follow this and additional works at: http://epublications.bond.edu.au/slej

Part of the Entertainment, Arts, and Sports Law Commons

Recommended Citation

Konstantinos Margaritis. (2015) "Constitutional Dimensions of Sport in Greece" „, : ISSN 1836-1129.

http://epublications.bond.edu.au/slej/25

This Journal Article is brought to you by the Faculty of Law at ePublications@bond. It has been accepted for inclusion in Sports Law eJournal by an authorized administrator of ePublications@bond. For more information, please contact Bond University's Repository Coordinator. 


\title{
Constitutional Dimensions of Sport in Greece
}

\begin{abstract}
Sports play an important role within development of personality and society in general. Affirming this importance, the Constitution of Greece acknowledges the right to sports as a fundamental right. Furthermore, in certain cases, this may lead to restriction of other fundamental rights guaranteed in the Constitution, in favour of sports. Issues arise regarding those restrictions and the necessity of recognition of sports in the highest level within the legal system of a country, the Constitution.
\end{abstract}

\section{Keywords}

right to sports, limitation of fundamental rights, sports justice, Greece

\section{Disciplines}

Entertainment, Arts, and Sports Law 


\title{
CONSTITUTIONAL DIMENSIONS OF SPORT IN GREECE
}

\author{
KONSTANTINOS MARGARITIS*
}

\begin{abstract}
Sport plays an important role within development of personality and society in general. Affirming this importance, the Constitution of Greece acknowledges the right to sports as a fundamental right. Furthermore, in certain cases, this may lead to restriction of other fundamental rights guaranteed in the Constitution, in favour of sports. Issues arise regarding those restrictions and the necessity of recognition of sports in the highest level within the legal system of a country, the Constitution.
\end{abstract}

\section{INTRODUCTION}

Every day, thousands of people around the world participate in sports either as players or fans. If the impact of sports in society is indisputable, even more important is the role that sport is called to play. 'Healthy mind in a healthy body' was the main opinion in ancient Greece, an opinion that contains all positive aspects of sports in the shaping of the personality of the citizen. Essentially, 'sport' is a combination of physical and mental activity, governed by a set of rules or customs with social, educational and cultural dimensions. From a social perspective, the purpose of sports is to elevate the values of social participation and inspiration, values that are particularly fundamental within the general concept of democracy.

This is the main reason why sports is characterized as a fundamental social right by the official State and therefore protected at the constitutional level in Greece. The free exercise of sports contributes to the general constitutional guarantee of free development of personality. Nevertheless, the Constitution of Greece contains a special provision for sports, putting its promotion under the supervision of the State. As a result of the constitutional guarantee of sports, the free exercise of this right may create conflicts with other fundamental rights protected in the Greek legal order, a fact that can lead to certain rights being limited.

This article focuses on the constitutional guarantee of sports as a fundamental right in Greece. Cases of possible conflict with other fundamental rights will be examined and a main outline of the sports justice system will be drawn. The aim is to give a complete presentation of the constitutional dimensions of sports in Greece.

\section{SPORTS AS A CONSTITUTIONALLY RECOGNIZED, FUNDAMENTAL RIGHT}

The Constitution of the Third Hellenic Republic ${ }^{1}$ was the first attempt in the constitutional history of the country to guarantee the right to sports. ${ }^{2}$ Article 16, para 9 explicitly states: 'sports shall be under the protection and the ultimate supervision of the State. The State shall make grants to and shall control all types of athletic associations, as specified by law. The use of grants in accordance with the purpose of the associations receiving them shall also be specified by law'. Besides this explicit reference, physical education is considered to be a basic aim of education in Greece, according to article 16, para 2 of the Constitution. Participating in sports is also considered to be protected as an aspect of the development of personality. $^{3}$

A first observation is that the provision of sports is included in article 16, which refers to freedom of education, arts and science. This implies the importance of sports within society and demonstrates the particular significance of sport in the culture of Greece. The obligations of the State extend from 'protection' to 'ultimate supervision'. From one perspective, the State protects sports as a civil right, in the sense that everybody has the right to participate in their chosen sport. The State is obliged to provide the

* LLM, PhD candidate National and Kapodistrian University of Athens, Attorney at Law.

1 The Constitution was established in 1975 after the fall of the military junta and restoration of democracy. It has been revised three times; in 1986, 2001 and 2008.

2 In most of the EU Member States there is no explicit constitutional provision protecting sports as a fundamental right; examples could be Germany, the Netherlands, Belgium and France where the protection and promotion of sports derives from provisions related to freedom of arts and science. Other countries where sports is autonomously protected is Spain (article 43 of the Spanish Constitution) and Portugal (article 79 of the Portuguese Constitution).

3 E Venizelos, 'Constitution and Sports' (1993) 1 International Sports Law Review: Pandektis 212, 212-14 (in Greek). 
necessary facilities for sporting activities. Furthermore, the State is under the obligation to promote sports by encouraging citizens, especially youngsters, to participate by organizing specific programs and events at all educational levels. This interpretation is in line with article 16, para 2 which reinforces physical education in Greece.

However, the description of article 16, para 9 creates interpretational issues as of the full guarantee of sports as a civil right. Unlike the provisions protecting other civil rights, ${ }^{4}$ article 16, para 9 does not include any assessment that provides the citizen with the opportunity to defend himself/herself against abuse by authorities. Therefore, sports may be considered akin to a social right ${ }^{5}$ in the sense that the citizen may claim positive action in respect of the State, namely the development of institutional framework, economic support, promotion and progress of sports. This is also in line with the inclusion of the provision in article 16 (freedom of education, art and science) which guarantees a traditionally social right. ${ }^{6}$

According to article 16, para 9, sport is under the ultimate supervision of the State. Under this approach, a constitutional supervision of legitimacy is imposed upon sports activities, ${ }^{7}$ especially at the professional level. For example, the economic status of incorporated companies that participate in professional sports are controlled by the relevant State authorities. The State shall also control all types of athletic associations regarding the use of grants to be in accordance with the purpose of the associations receiving them.

Another obligation of the State is of administrative nature. The second subparagraph of article 16, par. 9 of the Greek Constitution expressly cites that "the State shall make grants to and shall control all types of athletic associations, as specified by law. The use of grants in accordance with the purpose of the associations receiving them shall also be specified by law". The State is obliged to cope for the establishment of athletic associations of all kinds (all sports and in all levels). Subparagraph 2 also places a requirement on the State to finance sports associations in order for them to achieve the purposes of their establishment. Furthermore, the law specifies the use of the grants made by the State. This provision creates a "special" relationship between the State and the sport associations. Associations can use the grants given to them by the State for the purposes that they decide, however, the State can control if those purposes are related to the general objectives of sports associations. In that sense, sport associations are autonomous as institutions under a special framework. This action should always be in accordance with the main aim of sports which is the complete development of the personality of the citizen.

The protection of article 16, para 9 extends to anyone actively participating in sport activities, not only amateur or professional athletes individually, but also groups of people forming a team or an organization, even temporarily. Sports institutes, companies and other forms of association are also included. In addition, other professions related to sports enjoy protection of article 16, para 9, such as coaches and referees. Fans are in some sense passive 'participants' in sports events. By attending a specific event, they exercise their right to sports through the freedom of choosing sport and the freedom to express their sporting spirit.

Exercising the right to participate in sports activities is tightly connected to the freedom of development of personality protected by the Constitution in article 5 , para 1 . The freedom of development of personality implies that the athlete enjoys absolute freedom in choosing the sports organization. Hence, every athlete, amateur or professional, is entitled to freely participate in events established by sporting bodies, but is obliged to follow the rules of those bodies'. ${ }^{8}$ Limits based on nationality are set in the case of national teams, where the options of the athlete are restricted.

\section{LIMITATIONS OF FUNDAMENTAL RIGHTS IN FAVOUR OF SPORTS9}

According to article 41, par. 1 of Law 2725/1999 (hereinafter: Sports Law), ${ }^{10}$ all participants in sports events shall respect the rules of sports spirit; paragraph 2 adds that the abovementioned participants, in

\footnotetext{
4 For example, article 17 of the Greek Constitution (right to property) provides that 'no one shall be deprived of his property except for public benefit which must be duly proven, when and as specified by statute and always following full compensation corresponding to the value of the expropriated property at the time of the court hearing on the provisional determination of compensation. In cases in which a request for the final determination of compensation is made, the value at the time of the court hearing of the request shall be considered'.

5 A Malatos, Epistemological Approach to Sports Law (2000) 116-132 (in Greek).

6 Ibid.

Above $n 3$.

8 C-415/93 Union Royale Belge des Sociétés de Football Association ASBL vs Jean-Marc Bosman [1995] ECR I-4921. See also AL Lee, 'The Bosman Case: Protecting Freedom of Movement in European Football' (1995) 19 Fordham Journal of International Law 1254.

9 See on the issue, I Panagakou-Georgopoulou, 'Constitution and Sports' (2006) at http://www.greeklaws.com/pubs/uploads/1882.pdf, 19-20 (in Greek).
} 
particular players, coaches, managers, members of sports clubs' board, members of sports organizations and referees, shall not make any public statement, especially via the press, in order not to disturb the course of the games. At first, those provisions manifestly contradict with article 14, par. 1 of the Constitution which guarantees the freedom of expression; it states that "every person may express and propagate his thoughts orally, in writing and through the press in compliance with the laws of the State".

However, the rationale behind the sports law provision is of highest importance: combating hooliganism. A possible statement of one referee about a mistake for example, could have tremendous effects and end up being catastrophic for the game. Hence, the aim of restriction is to keep a certain amount of balance before, during and after the game. However, despite the fact that the restriction of statements can be justified for the purpose of balance, ${ }^{11}$ extreme cases should also been avoided. In this regard, the principle of proportionality shall apply; therefore public statements on behalf of the main protagonists of the game shall not be generally prohibited, but examined on a case by case basis. Since the aim of restriction of expression is to avoid intense statements, freedom of expression could be restricted on in cases that such statements occur.

Another right that is affected in the case of sports events is that of freedom of assembly. Article 41B of the Sports Law dictates that organized groups of fans shall be supervised by the General Secretariat for Sports. That specific requirement for sports fan organizations is unique in comparison to all other forms of assembly. The approach applied in article 41B highlights a sense of preventing some series of events. By supervising groups of fans, the State is in better position to distinguish from the beginning indications of illegal actions and act accordingly. During sports events, especially in football games, organized group of fans of a particular team may be prohibited from entering the stadium. As in the aforementioned cases, the aim of this restriction is to avoid uncontrollable situations, as expression of hooliganism, during the sports event. Other specific examples that restrict freedom of assembly could be the police control before entering a stadium, as well as the presence of the police during the event.

Finally, constitutional rights that have been manifestly restricted because of a main sports event are those related to rights to property as guaranteed in article 17 of the Constitution. In particular, paragraph 2 prohibits deprivation of property except for dully proven public benefit and always after full compensation. Whether sports events can be characterized as expressing "public benefit" is probably the main question; however, private properties were deprived without proper remuneration as well as wetlands, lakes and other natural systems were transformed for the construction of the premises needed during the organization of the Olympic Games in Athens in 2004. This had raised a large number of cases against the State.

\section{JUSTICE IN SPORTS}

Another important aspect that demonstrates the importance of sport in society is the separate justice system. Article 16, para 9 of the Constitution empowers the legislative to establish laws regarding the supervision of Sport by the State. Law 2725/1999 provides for the system of justice in sports within the general legal system. In Greece there are two level of jurisdiction in sports: the jurisdictional body of first instance; and the Supreme Council of Dispute Resolution in Sports, which acts as a 'court of appeal' concerning the decisions of the jurisdictional body of first instance.

The tribunal of first instance has jurisdiction to hear cases concerning bribery in sports, objections to the result of a game and disciplinary violations. The decisions of the jurisdictional body of first instance, as well as the decisions of the sports associations and of the disciplinary bodies of sports clubs, can be appealed to the Supreme Council of Dispute Resolution in Sports (under the conditions set out in article 121 of the Sports Law). In the districts of Athens, Piraeus and Thessaloniki, a special Public Prosecutor is appointed who is responsible for the prosecution of sports-related crimes, including those either committed during the event itself or connected to the event, such as hooliganism. In cases of further demands, the Courts of Civil Justice have jurisdiction as those disputes are of a private law nature. ${ }^{12}$

In addition, sanctions can be imposed on sports organizations and their boards, athletes, coaches and fans from institutions of administration. In line with the supervision of State in sports, article $41 \mathrm{Z}$ of the Sports Law sets disciplinary and other sanctions in cases of violation of articles $41-41 \Sigma \mathrm{T}$ for all factors that

\footnotetext{
10 Law 2725/1999 has been revised several times. The most important revisions were by Law 2858/2000, by Law $2947 / 2001$, by Law $3057 / 2002$, by Law 3262/2004 and most recently by Law $4049 / 2012$. As long as the framework remained the same it is more convenient to refer to Law 2725/1999 as the Sports Law.

11 D Panagiotopoulos The Right to Sports (1994) 51-54 (in Greek).

12 K Remelis, 'Legal Nature of Disciplinary Sports Disputes' (1994) Armenopoulos 101, 105.
} 
participate in one or another way in sports. Those sanctions contain fines up to 100.000 Euros as well as prohibition of fans for a number of games, depending on the seriousness of the violation.

\section{CONCLUSION}

The Constitution of Greece contains a rather general provision for the protection of sports. Its purpose for existence is primarily symbolic; to strengthen the importance of sports within society and its connection to the education of Greek citizens. Besides the symbolic contribution, article 16, para 9 does not add much to what we have seen is the natural development of sport in other countries with their different legal systems. Nonetheless, as in those other countries, the right to sport has developed to the extent where it appears to override other, more traditionally-established rights.

However, it can be argued that the protection given under article 16, par. 9 of the Greek Constitution is sufficient for the State to protect and develop the sports culture in Greece. Problems that have arisen in certain sports events should not be dealt with by restricting fundamental rights. The most effective way to combat them is by making brave political decisions. We are really looking for a change in social attitudes, facilitated by courageous decision-making. The rather vague legal decisions should be replaced with the will for establishing a new paradigm of exercising sports, as in the example of ancient Greece. 